\title{
Chemical composition and biological activity of the essential oil from Helichrysum microphyllum Cambess. ssp. tyrrhenicum Bacch., Brullo e Giusso growing in La Maddalena Archipelago, Sardinia.
}

\author{
Luigi Ornano ${ }^{1,2}$, Alessandro Venditti ${ }^{1,5 *}$, Cinzia Sanna ${ }^{2,3}$, Mauro Ballero ${ }^{2,3}$, \\ Filippo Maggi ${ }^{4}$, Giulio Lupidi ${ }^{4}$, Massimo Bramucci ${ }^{4}$, Luana Quassinti ${ }^{4}$ and \\ Armandodoriano Bianco ${ }^{1,2}$ \\ ${ }^{1}$ Dipartimento di Chimica, Sapienza Università di Roma, P.le A.Moro, 5, 00185 Roma \\ ${ }^{2}$ CoSMeSe, Dipartimento di Scienze della Vita e dell'Ambiente, Università di Cagliari, Via S. Ignazio da Laconi 11, 09123 Cagliari. \\ ${ }^{3}$ Dipartimento di Scienze della Vita e dell'Ambiente, Università di Cagliari, Via S. Ignazio da Laconi 11, 09123 Cagliari. \\ ${ }^{4}$ Scuola di Scienze del Farmaco e dei Prodotti della Salute, Università di Camerino. \\ ${ }^{5}$ Dipartimento di Biologia Ambientale, Sapienza Università di Roma
}

\begin{abstract}
Helichrysum microphyllum Cambess. subsp. tyrrhenicum Bacch., Brullo e Giusso (Asteraceae), previously known as Helichrysum italicum ssp. microphyllum (Willd.) Nyman, is one of the many endemic species growing in Sardinia, Corsica and Balearic Islands. In the present work the composition of the essential oil obtained from a population of $\mathrm{H}$. microphyllum ssp. thyrrenicum growing in a littoral location of La Maddalena Archipelago was investigated by GC-FID and CG-MS. The major compounds of the oil were the monoterpene ester neryl acetate (18.2\%), the oxygenated sesquiterpene 5-eudesmen-11-ol (rosifoliol, $11.3 \%$ ), the sequiterpene hydrocarbons $\delta$-cadinene $(8.4 \%)$ and $\gamma$-cadinene $(6.7 \%)$, showing a peculiar composition in comparison with other Sardinian populations. The oil was tested for cytotoxicity on three human tumor cell lines (MDA-MB 231, HCT116 and A375) by MTT assay showing a strong inhibitory activity on human malignant melanoma cells $\mathrm{A375}\left(\mathrm{IC}_{50}\right.$ of $\left.16 \mu \mathrm{g} / \mathrm{ml}\right)$. In addition the oil was assessed for antioxidant activity by DPPH and ABTS assay.
\end{abstract}

Key words: Helichrysum, neryl acetate, rosifoliol, $\delta$-cadinene, $\gamma$-cadinene

\section{Introduction}

Helichrysum microphyllum subsp. tyrrhenicum (Asteraceae), is one of the many endemic species growing in Sardinia, Corsica and Balearic Islands.

This plant is a shrub, $25-40 \mathrm{~cm}$ in height, strongly aromatic, with linear leaves, the lower not longer than $12 \mathrm{~mm}$; the flowers are grouped in yellow heads and fruits are brown achenes ${ }^{1)}$. It is used in Sardinian traditional medicine to nurse cough, burns and as antirheumatic and analgesic $^{2)}$.

There are several studies on the essential oils of Helychrysum species and their activity, such as antispasmodic, antioxidant, antibacterial and antiallergic ${ }^{3-6)}$. Alike, many are the phytoproducts isolated from the genus Helichrys$u m$ (s.l.), although few oils and extracts are used in the food, cosmetics and pharmaceutical industries. H. microphyllum subsp. tyrrhenicum is less widespread with respect to the other subspecies, and its chemical composition is peculiar with respect to plants growing in the peninsula. In particular from this subspecies a heterodimeric phloroglucinol pyrone arzanol endowed with interesting biological activities as well as an unusual class of lipids named santinols have been recently characterized ${ }^{7,8)}$.

H. italicum was proven to exhibit both morphological and genetic variation among and within the Mediterranean and Sardinian populations ${ }^{9,10)}$. This variability influenced the volatile composition with quali-quantitative differences in essential oils among populations coming from different regions ${ }^{11-15)}$. Therefore, our aim was to verify if geographical isolation in La Maddalena Archipelago lead to differenc-

\footnotetext{
*Correspondence to: Alessandro Venditti, Dipartimento di Chimica, Sapienza Università di Roma

E-mail: alessandro.venditti@uniroma1.it

Accepted September 16, 2014 (received for review August 2, 2014)

Journal of Oleo Science ISSN 1345-8957 print / ISSN 1347-3352 online

http://www.jstage.jst.go.jp/browse/jos/ http://mc.manusriptcentral.com/jjocs
} 
Table 1 Essential oil composition of Helichrysum microphyllum subsp. tyrrhenicum.

\begin{tabular}{|c|c|c|c|c|c|c|}
\hline \multirow{2}{*}{ N. } & \multirow{2}{*}{ Component $^{\mathrm{a}}$} & \multirow{2}{*}{$\mathrm{RI}^{\mathrm{b}}$} & \multicolumn{2}{|c|}{$\mathrm{RI} \mathrm{lit}^{\mathrm{c}}$} & \multirow{2}{*}{$\%^{d}$} & \multirow{2}{*}{$\mathrm{ID}^{\mathrm{e}}$} \\
\hline & & & ADAMS & NIST08 & & \\
\hline 1 & nerol & 1230 & 1229 & 1230 & 1.3 & RI,MS \\
\hline 2 & 2-undecanone & 1296 & 1294 & 1296 & 0.1 & RI,MS \\
\hline 3 & silphinene & 1334 & 1347 & & 0.1 & RI,MS \\
\hline 4 & $\alpha$-ylangene & 1366 & 1375 & 1366 & 0.0 & RI,MS \\
\hline 5 & neryl acetate & 1369 & 1361 & 1369 & 19.2 & RI,MS \\
\hline 6 & $\alpha$-isocomene & 1377 & 1388 & & 0.7 & RI,MS \\
\hline 7 & italicene & 1394 & 1405 & & 0.7 & RI,MS \\
\hline 8 & $\alpha$-gurjunene & 1400 & 1407 & & 0.1 & RI,MS \\
\hline 9 & (E)-caryophyllene & 1409 & 1418 & 1410 & 0.8 & Std \\
\hline 10 & $\gamma$-elemene & 1430 & 1436 & & 0.2 & RI,MS \\
\hline 11 & aromadendrene & 1430 & 1441 & 1429 & 0.2 & RI,MS \\
\hline 12 & 6,9 -guaiadiene & 1438 & 1444 & & 0.1 & RI,MS \\
\hline 13 & $\alpha$-humulene & 1445 & 1454 & 1446 & 0.3 & Std \\
\hline 14 & allo-aromadendrene & 1452 & 1460 & 1452 & 2.0 & RI,MS \\
\hline 15 & neryl propanoate & 1458 & 1454 & & 3.6 & RI,MS \\
\hline 16 & trans-cadina-1(6),4-diene & 1468 & 1476 & & 0.3 & RI,MS \\
\hline 17 & $\gamma$-muurolene & 1471 & 1479 & 1473 & 1.6 & RI,MS \\
\hline 18 & $\alpha$-amorphene & 1474 & 1484 & 1474 & 1.2 & RI,MS \\
\hline 19 & $\alpha$-neocallitropsene & 1477 & 1476 & & 0.7 & RI,MS \\
\hline 20 & ar-curcumene & 1480 & 1480 & 1480 & 0.7 & RI,MS \\
\hline 21 & $\delta$-selinene & 1485 & 1492 & 1485 & 0.5 & RI,MS \\
\hline 22 & cis-cadina,1-4-diene & 1487 & 1495 & & 1.2 & RI,MS \\
\hline 23 & $\alpha$-muurolene & 1494 & 1500 & 1494 & 2.5 & RI,MS \\
\hline 24 & $\delta$-amorphene & 1500 & 1512 & & 0.2 & RI,MS \\
\hline 25 & $\gamma$-cadinene & 1507 & 1513 & 1507 & 6.7 & RI,MS \\
\hline 26 & trans-calamenene & 1518 & 1522 & 1518 & $\operatorname{tr}^{\mathrm{f}}$ & RI,MS \\
\hline 27 & $\delta$-cadinene & 1519 & 1523 & & 8.4 & RI,MS \\
\hline 28 & trans-cadina,1-4-diene & 1526 & 1534 & 1525 & 1.0 & RI,MS \\
\hline 29 & $\alpha$-cadinene & 1531 & 1538 & 1532 & 1.2 & RI,MS \\
\hline 30 & $\alpha$-calacorene & 1536 & 1545 & & 0.8 & RI,MS \\
\hline 31 & geranyl butanoate & 1541 & 1564 & 1540 & 0.2 & RI,MS \\
\hline 32 & germacrene B & 1547 & 1561 & 1547 & 0.4 & RI,MS \\
\hline 33 & gleenol & 1579 & 1587 & & 0.3 & RI,MS \\
\hline 34 & neryl isovalerate & 1586 & 1583 & & 1.3 & RI,MS \\
\hline 35 & guaiol & 1592 & 1600 & 1592 & 1.9 & RI,MS \\
\hline 36 & rosifoliol & 1598 & 1600 & & 11.3 & RI,MS \\
\hline 37 & 1,10-di-epi-cubenol & 1606 & 1619 & & 0.6 & RI,MS \\
\hline 38 & tetradecanal & 1613 & 1612 & 1613 & 0.3 & RI,MS \\
\hline 39 & 1-epi-cubenol & 1621 & 1628 & & 1.5 & RI,MS \\
\hline 40 & muurola-4,10(14)-dien-1- $\beta$-ol & 1621 & 1631 & & 1.5 & RI,MS \\
\hline
\end{tabular}


Table 1 Continued.

\begin{tabular}{|c|c|c|c|c|c|c|}
\hline \multirow{2}{*}{$\mathrm{N}$. } & \multirow{2}{*}{ Component $^{\mathrm{a}}$} & \multirow{2}{*}{$\mathrm{RI}^{\mathrm{b}}$} & \multicolumn{2}{|c|}{$\mathrm{RI}_{\mathrm{lit}}{ }^{\mathrm{c}}$} & \multirow{2}{*}{$\%^{\mathrm{d}}$} & \multirow{2}{*}{$\mathrm{ID}^{\mathrm{e}}$} \\
\hline & & & ADAMS & NIST08 & & \\
\hline 41 & $\beta$-eudesmol & 1627 & 1650 & 1630 & 1.3 & RI,MS \\
\hline 42 & epi- $\alpha$-cadinol & 1634 & 1640 & & 2.0 & RI,MS \\
\hline 43 & epi- $\alpha$-muurolol & 1634 & 1642 & & 2.0 & RI,MS \\
\hline 44 & $\alpha$-muurolol & 1641 & 1646 & & 1.5 & RI,MS \\
\hline 45 & $\alpha$-eudesmol & 1644 & 1653 & 1644 & 0.5 & RI,MS \\
\hline 46 & $\alpha$-cadinol & 1648 & 1654 & 1650 & 1.5 & RI,MS \\
\hline 47 & bulnesol & 1660 & 1671 & 1662 & 0.8 & RI,MS \\
\hline 48 & cadalene & 1667 & 1676 & 1668 & 0.3 & RI,MS \\
\hline 49 & geranyl tiglate & 1674 & 1696 & 1675 & 0.4 & RI,MS \\
\hline 50 & pentadecanal & 1714 & & 1717 & 1.2 & RI,MS \\
\hline 51 & drimenol & 1769 & 1767 & & 0.2 & RI,MS \\
\hline 52 & 2-pentadecanone, 6,10,14-trimethyl- & 1846 & & 1846 & 1.3 & RI,MS \\
\hline 53 & pimaradiene & 1943 & 1949 & 1947 & 0.2 & RI,MS \\
\hline 54 & $n$-pentacosane & 2500 & 2500 & 2500 & 0.1 & Std \\
\hline 55 & $n$-heptacosane & 2700 & 2700 & 2700 & 0.1 & Std \\
\hline 56 & $n$-nonacosane & 2900 & 2900 & 2900 & 0.1 & Std \\
\hline 57 & $n$-untriacontane & 3100 & 3100 & 3100 & 0.1 & Std \\
\hline
\end{tabular}

Total identified

Grouped compounds

Monoterpene esters

Oxygenated monoterpenes

Sesquiterpene hydrocarbons

Oxygenated sesquiterpenes

Others

2.2

\begin{abstract}
${ }^{a}$ Compounds are listed in order of their elution from a HP-5MS column. ${ }^{b}$ Linear retention index on HP-5MS column, experimentally determined using homologous series of $\mathrm{C}_{8}-\mathrm{C}_{30}$ alkanes. ${ }^{\circ}$ Linear retention index taken from Adams (2007) and NIST 08 (2008). ${ }^{\mathrm{d}}$ Percentage values are means of three determinations with a RSD\% in all cases below $10 \%{ }^{\mathrm{e}}$ Identification methods: std, based on comparison with authentic compounds; MS, based on comparison with WILEY, ADAMS and NIST 08 MS databases; RI, based on comparison of LRI with those reported in ADAMS, FFNSC 2 and NIST $08 .{ }^{\mathrm{f}}$ tr, $\%$ below $0.1 \%$.
\end{abstract}

es in essential oil composition of H. microphyllum subsp. tyrrhenicum with respect to other areas of Sardinia, as resulted for A. arborescens in our previous paper ${ }^{16)}$. To complete the work, we assayed the essential oil for cytotoxicity against some tumor cell lines by the MTT method, and for antioxidant activity by DPPH, ABTS and FRAP methods.

\section{Results and discussion}

\subsection{Essential oil Analysis}

The composition of the essential oil from aerial parts of
Helichrysum microphyllum subsp. tyrrhenicum growing in the Isle of La Maddalena (Sardinia, Italy), is reported in Table 1. A total of fifty-seven volatile components were identified, accounting for $89.7 \%$ of the total composition. The major compounds were neryl acetate $(19.2 \%)$, $\delta$-cadinene $(8.4 \%)$ and rosifoliol $(11.3 \%)$, which are representative of monoterpene esters $(24.7 \%)$, sesquiterpene hydrocarbons (33.1\%) and oxygenated sesquiterpenes $(28.3 \%)$, respectively. Instead, completely missing resulted the monoterpene hydrocarbons. Other components occurring in significant amounts $(\geq 2 \%)$ were neryl propanoate $(3.6 \%)$ for monoterpene esters, $\gamma$-cadinene $(6.7 \%)$, 
Table 2 Major volatile constituents ( $>5 \%)$ of Sardinian samples of H. microphyllum ssp. thyrrenicum.

\begin{tabular}{|c|c|c|}
\hline Origin & Major constituents & Reference \\
\hline $\begin{array}{l}\text { Sardinia (location not } \\
\text { specified) }\end{array}$ & $\begin{array}{l}\text { Group 1: linalool }(9.1 \%) \text {, nerol }(10.7 \%) \text {, neryl acetate }(28.9 \%) \text {, neryl } \\
\text { propionate }(11.4 \%), \gamma \text {-curcumene }(11.4 \%) \text {. Group } 2 \text { : linalool }(14.9 \%) \text {, } \\
\gamma \text {-curcumene }(18.2 \%), \delta \text {-cadinene }(5.6 \%), 2 \text {-naphthalenmethanol,2,3,4, } \\
4 \mathrm{a}, 5,6,7,8 \text {-octahydro- } \alpha, \alpha, 4 \mathrm{a}, 8 \text {-tetramethyl-[2R- }(2 \alpha, 4 \mathrm{a} \beta, 8 \beta 9](20.2 \%)\end{array}$ & 11) \\
\hline $\begin{array}{l}\text { Northwestern Sardinia } \\
\text { (Vignola, Porto Ferro, } \\
\text { Calangianus) }\end{array}$ & $\begin{array}{l}\text { linalool }(3.7-5.6 \%) \text {, nerol }(5.3-8.1 \%) \text {, neryl acetate }(44.7-52.5 \%) \text {, eudesm-5- } \\
\text { en-11-ol }(4.3-11.5 \%)\end{array}$ & 12) \\
\hline $\begin{array}{l}\text { Central Sardinia } \\
\text { (Esterzili) }\end{array}$ & $\begin{array}{l}\text { limonene }(2.5-9.0 \%) \text {, linalool }(7.4-26.5 \%) \text {, nerol }(5.3-13.5 \%) \text {, neryl acetate } \\
(20.0-35.7 \%) \text {, neryl propionate }(1.9-15.6 \%), \gamma \text {-curcumene }(7.3-17.1 \%) \text {, ar- } \\
\text { curcumene }(4.0-6.8 \%) \text {, rosifoliol }(5.8-15.1 \%)\end{array}$ & 13) \\
\hline $\begin{array}{l}\text { Northwestern Sardinia } \\
\text { (Costa Paradiso, Trinità } \\
\text { d' Agultu, Calangianus) }\end{array}$ & $\begin{array}{l}\text { April samples: } \alpha \text {-terpineol }(1.5-6.7 \%) \text {, nerol }(3.4-6.3 \%) \text {, neryl acetate }(28.1- \\
55.9 \%) \text {, neryl propionate }(2.3-5.8 \%) \text {, eudesm-5-en-11-ol }(4.5-21.5 \%)\end{array}$ & 15) \\
\hline $\begin{array}{l}\text { Northeastern Sardinia } \\
\text { (La Maddalena) }\end{array}$ & $\begin{array}{l}\text { neryl acetate }(19.2 \%), \gamma \text {-cadinene }(6.7 \%), \delta \text {-cadinene }(8.4 \%) \text {, rosifoliol } \\
(11.3 \%)\end{array}$ & \\
\hline
\end{tabular}

Table 3 In vitro cytotoxic activity of Helichrysum microphyllum subsp. tyrrhenicum essential oil.

\begin{tabular}{lccc}
\hline \multirow{2}{*}{ Essential oil } & \multicolumn{3}{c}{ Cell line $\left(\mathrm{IC}_{50} \mu \mathrm{g} / \mathrm{ml}\right)$} \\
\cline { 2 - 4 } & MDA-MB 231 & HCT116 $^{\mathrm{b}}$ & $\mathrm{A}^{\mathrm{b}} 7^{\mathrm{c}}$ \\
\hline Helichrysum microphyllum subsp. tyrrhenicum & 44.29 & 29.38 & 16.03 \\
95\% C.I. & $40.58-49.9$ & $24.92-34.64$ & $12.50-20.54$ \\
Reference & & & \\
Cisplatin & 2.96 & 2.45 & 0.42 \\
95\% C.I. & $2.23-3.15$ & $2.05-2.89$ & $0.29-0.49$ \\
\hline
\end{tabular}

$\mathrm{IC}_{50}=$ The concentration of compound that affords a $50 \%$ reduction in cell growth (after $72 \mathrm{~h}$ of incubation). C.I. $=$ Confidence Interval. ${ }^{\mathrm{a}}$ Human breast adenocarcinoma cell line. ${ }^{\mathrm{b}}$ Human colon carcinoma cell line.

${ }^{\mathrm{c}}$ Human malignant melanoma cell line.

$\alpha$-muurolene (2.5\%) and allo-aromadendrene(2.0\%) for sesquiterpene hydrocarbons, epi- $\alpha$-cadinol $(2.0 \%)$ and epi- $\alpha$-muurolol $(2.0 \%)$ for oxygenated sesquiterpenes.

Comparing our results with those reported in literature ${ }^{11-15,17)}$, we can notice similarities in the composition taking into account such an inter-populations variability linked to genetic, geographic and climatic factors. Notably, the geographical isolation in La Maddalena Archipelago, could have led to the detected differences in the essential oil composition with respect to populations from different Sardinian locations (Table 2). The main features of the investigated population seem to be a lower content of neryl acetate and more in general of the oxygenated monoterpenes, the absence of monoterpene hydrocarbons together with that of linalool and $\gamma$-curcumene which are reported as two of the major components in other populations ${ }^{18)}$, and the high content (about $61 \%$ ) of sesquiterpenes among which $\gamma$-cadinene, $\delta$-cadinene and rosifoliol were the most representatives. In addition it has not been observed sub- stantial decreasing of the principal compounds between oils derived from fresh or dried plants ${ }^{15)}$.

\subsection{Cytotoxic activity}

Cytotoxic activity of the essential oil from Helichrysum microphyllum subsp. tyrrhenicum was evaluated on a selection of human tumour cell lines. MDA-MB 231 human breast adenocarcinoma, A375 human malignant melanoma, and HCT116 human colon carcinoma cell lines were tested by MTT assay. All cell lines were submitted to increasing concentrations of essential oil for $72 \mathrm{~h}$. The results show that essential oil exhibited a significant cytotoxicity against the human tumour cells examined (Table 3 ). The essential oil induced a concentration-dependent inhibitory effect on all cell lines tested in the dilutions ranging from 1.56 to 400 $\mu \mathrm{g} / \mathrm{ml}$. The $\mathrm{IC}_{50}$ values of the oil were $16.03,29.38$, and $44.29 \mu \mathrm{g} / \mathrm{ml}$ on the A375, HCT116 and MDA-MB 231 cell lines, respectively. The essential oil resulted active mainly on human melanoma cell line. 
Table 4 In vitro radical scavenging activities of the essential oil from Helichrysum microphyllum subsp. tyrrhenicum.

\begin{tabular}{|c|c|c|c|c|c|}
\hline \multirow[b]{2}{*}{ Essential oil } & \multicolumn{2}{|c|}{ DPPH } & \multicolumn{2}{|c|}{ ABTS } & \multirow{2}{*}{$\begin{array}{c}\text { FRAP } \\
\text { TEAC } \\
\mu \mathrm{mol} \mathrm{TE} / \mathrm{g}\end{array}$} \\
\hline & $\begin{array}{c}\text { TEAC } \\
\mu \mathrm{mol} \mathrm{TE} / \mathrm{g}\end{array}$ & $\begin{array}{c}\mathrm{IC}_{50} \\
\mu \mathrm{g} / \mathrm{ml}\end{array}$ & $\begin{array}{c}\text { TEAC } \\
\mu \mathrm{mol} \mathrm{TE} / \mathrm{g}\end{array}$ & $\begin{array}{c}\mathrm{IC}_{50} \\
\mu \mathrm{g} / \mathrm{ml}\end{array}$ & \\
\hline $\begin{array}{l}\text { Helichrysum microphyllum } \\
\text { subsp. tyrrhenicum }\end{array}$ & $20.3( \pm 1.7)$ & $2060.0( \pm 20)$ & $37.8( \pm 1.1)$ & $370.0( \pm 4.2)$ & $2.4( \pm 0.6)$ \\
\hline \multicolumn{6}{|l|}{ Reference } \\
\hline Trolox & & $10.7( \pm 0.2)$ & & $3.6( \pm 0.2)$ & \\
\hline
\end{tabular}

The chemical composition of the essential oil does not put in evidence the presence of a main compound that could be responsible for the cytotoxic activity. The main compounds present in the essential oil are neryl acetate $(19.2 \%)$, rosifoliol $(11.3 \%), \delta$-cadinene $(8.4 \%)$, and $\gamma$-cadinene $(6.7 \%)$. There are few data in literature related to cytotoxic activity of these compounds. Only $\delta$-cadinene has been reported to exert high cytotoxic activity on human breast carcinoma cell line BT-20 and human epithelial adenocarcinoma cell line $\mathrm{HeLa}^{19)}$. All the other compounds are present in the oil at concentrations below $3.6 \%$, the minor components could contribute to cytotoxicity or may be involved in some type of synergism with the other compounds.

\subsection{Antioxidant activity}

H. italicum is a medicinal plant with promising pharmacological activities that continues to play an important role in the traditional medicine of Mediterranean countries ${ }^{20)}$. The plant is widely used due to different properties as antiinflammatory $^{20)}$, antibacterial $^{8,13,20)}$ and antioxidant ${ }^{4,6)}$. In the cosmetic field, products based on extracts and essential oil, have also anti-aging property, because they help to regenerate skin tissue and relieve inflammation through antioxidant properties which protect the skin from damaging free radicals $^{21)}$. H. italicum solvent extracts showed high antioxidant activity ${ }^{6,21,22)}$ while less activity is normally showed by essential oils owing to the lack of phenols.

Due to the interest on the use of this oil, in our work we characterized the antioxidant activity of the essential oil from $H$. microphyllum subsp. tyrrhenicum by DPPH and ABTS assays. All data are presented in Table 4. According to the results obtained by DPPH assay, the essential oil exhibited scavenging activity with an $\mathrm{IC}_{50}$ value about 187 fold higher than that reported for Trolox, while the total antioxidant power determined towards $\mathrm{ABTS}^{+}$assay showed an $\mathrm{IC}_{50}$ value of about 100-fold higher than that of Trolox. The different activity observed against the two radicals is probably due to the more specificity of the oil components towards $\mathrm{ABTS}^{+}$radical cation. The antioxidant ac- tivity of $H$. microphyllum subsp. tyrrhenicum oil was also determined by ferric reducing antioxidant power (FRAP) method. As reported in Table 4 the essential oil did not show important reducing ability. As regards the contribution of the oil components to the antioxidant activity, the major oil constituent (neryl acetate) is not known as a strong antioxidant, while the sesquiterpene alcohol rosifoliol (11.3\%) exhibited a significant, protective effect against linoleic acid oxidation ${ }^{6)}$. Nonetheless, other minor compounds may act as electron donors, contributing to the total activity of the oil.

\section{Experimental}

\subsection{Plant Materials}

Plant material was collected in La Maddalena Archipelago, located a short distance from the rugged north-east coast called Baia Trinita, at the beginning of the flowering stage (April 2013) The botanical identification was performed by Dr. Cinzia Sanna "Consorzio Interuniversitario Co.S.Me.Se." (Università di Cagliari). A sample of the studied plant is stored in our laboratory under the accession number: Herbarium CAG 729.

\subsection{Extraction of essential oil}

The fresh plant material(546 g) was subjected to hydrodistillation using a Clevenger type apparatus for $3 \mathrm{~h}$ according to the European Pharmacopoeia ${ }^{23)}$ (European Pharmacopoeia, 2002). The obtained hydro-distillate was extracted with hexane ( 3 times) and the organic layers was collected and dried on sodium sulfate. The organic solvent was eliminated at room temperature, under nitrogen flux. The obtained oil was stored in sealed vials under nitrogen atmosphere at $-20^{\circ} \mathrm{C}$ in the dark, until analysis. The essential oil was obtained in yield of $0.11 \%(\mathrm{w} / \mathrm{w})$.

\subsection{GC-FID and GC/MS analysis}

For gas chromatographic separations, an Agilent 4890D instrument coupled to an ionization flame detector (FID) 


\section{Ornano, A. Venditti, C. Sanna et al.}

was used. Volatile components were separated on a HP-5 capillary column (5\% phenylmethylpolysiloxane, $25 \mathrm{~m}, 0.32$ mm i.d.; $0.17 \mu \mathrm{m}$ film thickness) ( $J$ and $W$ Scientific, Folsom, CA), with the following temperature program: 5 min at $60^{\circ} \mathrm{C}$, subsequently $4{ }^{\circ} \mathrm{C} / \mathrm{min}$ up to $220^{\circ} \mathrm{C}$, then $11^{\circ} \mathrm{C} /$ min up to $280^{\circ} \mathrm{C}$, held for $15 \mathrm{~min}$, for a total run of $65 \mathrm{~min}$. Injector and transfer line temperatures were $280^{\circ} \mathrm{C}$. Helium was used as the carrier gas, at a flow rate of $1.4 \mathrm{ml} / \mathrm{min}$; injection volume: $1 \mu \mathrm{l}$; split ratio, 1:34. A mixture of aliphatic hydrocarbons (C8-C30) (Sigma, Milan, Italy) in $n$-hexane, was directly injected into the GC injector under the above temperature program, in order to calculate the linear retention index of each compound. Oil samples were diluted 1:100 in $n$-hexane and injected at a volume of $1 \mu \mathrm{l}$. Analysis was repeated three times. Data were collected by using HP3398A GC Chemstation software (Hewlett Packard, Rev. A.01.01). Quantification of essential oil components was obtained by FID peak-area internal normalization by using correction factors ${ }^{24)}$.

GC-MS analysis was performed on an Agilent 6890N gas chromatograph coupled to a $5973 N$ mass spectrometer using a HP-5MS (5\% phenylmethylpolysiloxane, 30 m, 0.25 mm i.d., $0.1 \mu \mathrm{m}$ film thickness) ( $J \& W$ Scientific, Folsom) capillary column. The temperature program was the same as above. Injector and transfer line temperatures were $280^{\circ} \mathrm{C}$. Helium was used as the carrier gas, at a flow rate of $1 \mathrm{ml} / \mathrm{min}$. Split ratio: 1:50; acquisition mass range: 29-400 $\mathrm{m} / z$. All mass spectra were acquired in electron-impact (EI) mode with an ionization voltage of $70 \mathrm{eV}$. Oil samples were diluted 1:100 in $n$-hexane and the volume injected was $2 \mu \mathrm{l}$. Data were analyzed by using MSD ChemStation software (Agilent, Version G1701DA D.01.00). Whenever possible volatile components were identified by co-injection with authentic standards purchased from Sigma-Aldrich (Milan, Italy). Otherwise, the peak assignment was carried out according to the recommendations of the International Organization of the Flavor Industry (IOFI, http://www.iofi.org/ $)^{25)}$, i.e., by the interactive combination of chromatographic linear retention indices that were consistent with those reported in MS libraries ${ }^{26,27)}$ for apolar stationary phases, and MS data consisting in the computer matching with the following libraries: WILEY275, NIST 08 and $A D A M S$. In addition, a home-made library, based on the analyses of reference oils and commercially available standards was used as well.

\subsection{Cytotoxicity assay}

MDA-MB 231 (human breast adenocarcinoma) and A375 cells (human malignant melanoma) were cultured in Dulbecco's Modified Eagle's Medium (DMEM) with $2 \mathrm{mM} \mathrm{L-}$ glutamine, $100 \mathrm{IU} / \mathrm{ml}$ penicillin, $100 \mu \mathrm{g} / \mathrm{ml}$ streptomycin, and supplemented with $10 \%$ heat-inactivated fetal bovine serum (HI-FBS). HCT116 (human colon carcinoma) cells were cultured in RPMI1640 medium with 2 mM L-gluta- mine, $100 \mathrm{IU} / \mathrm{ml}$ penicillin, $100 \mu \mathrm{g} / \mathrm{ml}$ streptomycin, and supplemented with $10 \%$ HI-FBS. Cells were cultured in a humidified atmosphere at $37^{\circ} \mathrm{C}$ in presence of $5 \% \mathrm{CO}_{2}$. The MTT assay was used as a relative measure of cell viability. Cell-viability assays were carried out as described by Quassinti $^{28)}$ et al.. Briefly, cells were seeded at the density of $2 \times 10^{4}$ cells $/ \mathrm{ml}$. After $24 \mathrm{~h}$, samples were exposed to different concentrations of essential oil. Ten experimental groups were tested with the following concentrations of essential oil: $0,1.56,3.125,6.25,12.5,25,50,100,200$, and $400 \mu \mathrm{g} / \mathrm{ml}$. Each group was performed in quadruplicate. Cells were incubated for $72 \mathrm{~h}$ in a humidified atmosphere of $5 \% \mathrm{CO}_{2}$ at $37^{\circ} \mathrm{C}$. At the end of incubation, each well received $10 \mu \mathrm{l}$ of 3-(4,5-dimethylthiozol-2-yl) 2-5 diphenyltetrazolium bromide (MTT) $(5 \mathrm{mg} / \mathrm{ml}$ in phosphate-buffered saline, PBS) and the plates were incubated for $4 \mathrm{~h}$ at $37^{\circ} \mathrm{C}$. The extent of MTT reduction was measured spectrophotometrically at $540 \mathrm{~nm}$ using a Titertek MultiscanmicroElisa (Labsystems, FI-Helsinki). Experiments were conducted in triplicate. Cytotoxicity was expressed as the concentration of compound inhibiting cell growth by $50 \%\left(\mathrm{IC}_{50}\right)$. The $\mathrm{IC}_{50}$ values were determined with GraphPad Prism 4 computer program (GraphPad Software, S. Diego, CA, USA).

\subsection{Antioxidant activity}

DPPH free radical scavenging activity was evaluated on a microplate analytical assay as previously described ${ }^{29)}$. Stock solution of DPPH was prepared methanol and stored at $-20^{\circ} \mathrm{C}$ until needed. The working solution was obtained by mixing stock solution with methanol to obtain an absorbance of 1 unit at $517 \mathrm{~nm}$. The absorbance of tested and blank control solutions (the same chemicals, except for the sample) was recorded spectrophotometrically at $517 \mathrm{~nm}$ after incubation for 30 min in the dark. Free Radical Scavenging Capacity (RSC) of solution was then calculated as percent inhibition according to the following equation:

$$
\operatorname{RSC}(\% \text { inhibition })=100\left(\mathrm{~A}_{(\text {blank })}-\mathrm{A}_{(\text {sample })}\right) / \mathrm{A}_{(\text {blank })}
$$

Antioxidant activity of the essential oil was expressed as $\mathrm{IC}_{50}$ values, which represented the concentrations of the essential oil that caused $50 \%$ inhibition; it was determined by linear regression analysis from the obtained RSC values. Trolox was used as reference. Results were expressed in $\mu$ moles of Trolox equivalents (TE)/g of essential oil.

ABTS assay, was performed following the procedure previously described by Re and coworkers ${ }^{30)}$, applied to a 96-well microplate assay ${ }^{31)}$. The $\mathrm{ABTS}^{+}$stock solution was prepared by mixing the two solutions of $\operatorname{ABTS}(7.4 \mathrm{mM})$ and potassium persulfate $(2.6 \mathrm{mM})$ in equal quantities and allowing them to react for $12 \mathrm{~h}$ in the dark at room temperature. The working solution was then obtained by mixing $\mathrm{ABTS}^{+}$solution with methanol to obtain a final solution with absorbance of 1 unit at $734 \mathrm{~nm}$ measured with a Varian Cary 1 spectrophotometer. Trolox was used as refer- 
ence. Results were expressed in $\mu$ moles Trolox equivalents (TE)/g of essential oil. The capacity of free radical scavenging $\left(\mathrm{IC}_{50}\right)$ was determined using the previously reported equation. All data were expressed as means \pm standard deviations $(\mathrm{SD})$ of triplicate measurements. The confidence limits were set at $p<0.05$. SD did not exceed $5 \%$ for the majority of the values obtained.

The FRAP assay was carried out as reported previous$\mathrm{ly}^{32)}$. The stock solutions contained $300 \mathrm{mM}$ acetate buffer, pH 3.6, 10 mM TPTZ (2, 4, 6- tripyridyl-s -triazine) solution in $40 \mathrm{mM} \mathrm{HCl}$, and $20 \mathrm{mM} \mathrm{FeCl}_{3} \cdot 6 \mathrm{H}_{2} \mathrm{O}$. The fresh working solution was prepared by mixing $25 \mathrm{~mL}$ acetate buffer, 2.5 mL TPTZ solution, and $2.5 \mathrm{~mL} \mathrm{FeCl}_{3} 6 \mathrm{H}_{2} \mathrm{O}$ solution and then warmed at $37^{\circ} \mathrm{C}$ before used. Aliquots of diluted oil solution in methanol allowed to react with $500 \mu \mathrm{L}$ of the FRAP solution in the dark for $30 \mathrm{~min}$. Samples were centrifuged at $10000 \mathrm{rpm}$ and aliquots $(280 \mu \mathrm{L})$, then withdrawn and read in 96-well microplates. Readings of the coloured product [ferrous tripyridyltriazine complex] were then carried out at $593 \mathrm{~nm}$. The standard curve was linear between 25 and $800 \mu \mathrm{M}$ Trolox (TE). Results were expressed in $\mu$ moles Trolox equivalents $(\mathrm{TE}) / \mathrm{g}$ of essential oil.

\section{Conclusions}

The composition detected in Helichrysum microphyllum subsp. tyrrhenicum growing in La Maddalena Archipelago confirmed the existence of a worthy chemical polymorphism among populations coming from different areas. In comparison to the composition of the oils from other populations our sample showed a lower content of neryl acetate $(19.2 \%)$ and a high content of sesquiterpenes (about 61\%). Moreover, other marker components detected in other Sardinian populations such as linalool and $\gamma$-curcumene are completely missing in our sample. We assume that geographical isolation affected the essential oil composition of the investigated population with respect to those from other regions of the Isle. The essential oil showed a significant cytotoxicity against the human tumor cell examined, notably on melanoma cells, deserving further studies for a possible use as anticancer agent. Finally, the antioxidant activity of the essential oil resulted weak as a consequence of the poorness of components endowed with hydrogen- or electron-donor functional groups.

\section{References}

1) Angiolini, C.; Bacchetta, G.; Brullo, S.; Casti, M.; Giusso Del Galdo, G.; Guarino R. The vegetation of mining dumps in SW-Sardinia. Feddes Repert. 116, 243-276
(2005).

2) Atzei, A. D. Le piante nella tradizione popolare della Sardegna. Carlo Delfino Editore. (2003).

3) Rigano, D.; Formisano, C.; Senatore, F.; Piacente, S.; Pagano, E.; Capasso, R.; Borrelli, F.; Izzo, A. A. Intestinal antispasmodic effects of Helichrysum italicum (Roth)Don ssp. italicum and chemical identification of the active ingredients. J. Ethnopharmacol. 150, 901-906 (2013).

4) Maffei, F. R.; Carini, M.; Franzoi, L.; Pirola, O.; Bosisio, E. Phytochemical characterization and radical scavenger activity of flavonoids from Helichrysum italicum G. Don(Compositae). Pharmacol. Res. 22, 709-721 (1990).

5) Nostro, A.; Bisignano, G.; Angela Cannatelli, M.; Crisafi, G.; Paola Germano, M.; Alonzo, V. Effects of Helichrysum italicum extract on growth and enzymatic activity of Staphylococcus aureus. Int. J. Antimicrob. Ag. 17, 517-520 (2001).

6) Rosa, A.; Deiana, M.; Atzeri, A.; Corona, G.; Incani, A.; Paola Melis, M.; Appendino, G.; Dessì, M. A. Evaluation of the antioxidant and cytotoxic activity of arzanol, a prenylated $\alpha$-pyrone-phloroglucinol etherodimer from Helychrysum italicum subsp. microphyllum. ChemBiol Interact. 165, 117-126 (2007).

7) Appendino, G.; Ottino, M.; Marquez, N.; Bianchi, F.; Giana, A.; Ballero, M.; Sterner, O.; Fiebich, B. L.; Munoz, E. Arzanol, an Anti-inflammatory and Anti-HIV-1 Phloroglucinol $\alpha$-Pyrone from Helichrysum italicum ssp. microphyllum. J. Nat. Prod. 70, 608-612 (2007).

8) Taglialatela-Scafati, O.; Pollastro, F.; Chianese, G.; Minassi, A.; Gibbons, S.; Arunotayanun, W.; Mabebie, B.; Ballero, M.; Appendino, G. Antimicrobial phenolics and unusual glycerides from Helychrysum italicum subsp. microphyllum. J. Nat. Prod. 76, 346-353 (2013).

9) Galbany-Casals, M.; Blanco-Moreno, J. M.; GarciaJacas, N.; Breitwieser, I.; Smissen, R. D. Genetic variation in Mediterranean Helichrysum italicum (Asteraceae; Gnaphalieae): do disjunct populations of subsp. microphyllum have a common origin? Plant Biol. 13, 678-687 (2011).

10) Melito, S.; Sias, A.; Petretto, G. L.; Chessa, M.; Pintore, G. Genetic and metabolite diversity of Sardinian populations of Helichrysum italicum. PLOS ONE 72, e79043 (2013).

11) Satta, M.; Tuberoso, C. I. G.; Angioni, A.; Pirisi, F. M.; Cabras, P. Analysis of the essential oil of Helichrysum italicum G. Don. Ssp. microphyllum (Willd) Nym. J. Essent. Oil Res. 11, 711-715(1999).

12) Bianchini, A. Tomi, P.; Bernardini, A. F.; Morelli, I.; Flamini, G.; Cioni, P. L.; Usai, M.; Marchetti, M. A comparative study of volatile constituents of two $\mathrm{He}$ lichrysum italicum(Roth) Guss. Don Fil subspecies 


\section{Ornano, A. Venditti, C. Sanna et al.}

growing in Corsica (France), Tuscany and Sardinia (Italy). Flavour Frag. J. 18, 487-491 (2003).

13) Angioni, A.; Barra, A.; Arlorio, M.; Coisson, J. D.; Russo, M. T.; Pirisi, F. M.; Satta, M.; Cabras, P. Chemical Composition, Plant Genetic Differences, and Antifungal Activity of the Essential Oil of Helichrysum italicum G. Don ssp. microphyllum (Willd) Nym. J. Agr. Food Chem. 51, 1030-1034(2003).

14) Perrini, R.; Morrone-Fortunato, I.; Lorusso, E.; Avato, P. Glands, essential oils and in vitro establishment of $\mathrm{He}^{-}$ lichrysum italicum (Roth) G. Don ssp. microphyllum (Willd.) Nyman. Ind. Crop Prod. 29, 395-403 (2009).

15) Usai, M.; Foddai, M.; Bernardini, A. F.; Muselli, A.; Costa, J.; Marchetti, M. Chemical composition and variation of the essential oil of wild Sardinian Helychrysum italicum G. Don subsp. microphyllum (Willd.) Nym from vegetative period to post-blooming. J. Essent. Oil Res. 22, 373-380 (2010).

16) Ornano, L.; Venditti, A.; Ballero, M.; Sanna, C.; Quassinti, L.; Bramucci, L.; Lupidi, G.; Papa, F.; Vittori, S.; Maggi, F.; Bianco, A. Chemopreventive and Antioxidant Activity of the Chamazulene-Rich Essential Oil Obtained from Artemisia arborescens L. Growing on the Isle of La Maddalena, Sardinia, Italy. Chem. Biodiv. 10, 1464-1474 (2013).

17) Marongiu, B.; Piras, A.; Desogus, E.; Porcedda, S.; Ballero, M. Analysis of the Volatile Concentrate of the Leaves and Flowers of Helychrysum italicum (Roth) Don ssp. microphyllum (Willd.) Nyman (Asteraceae) by Supercritical Fluid Extraction and Their Essential Oils. J. Essent. Oil Res. 15, 120-126 (2003).

18) Tucker, A. O.; Maclarello, M. J.; Charles, D. J.; Simon, J.E. Volatile leaf oil of the curry plant[Helichrysum italicum (Roth) G. Don subsp. italicum] and dwarf curry plant[subsp. microphyllym (Willd.) Nyman] in the North American Herb Trade. J. Essent. Oil Res. 9, XVII-XVIII (1997).

19) Kubo, I., Morimitsu, J. Cytotoxicity of green tea flavor compounds against two solid tumor cells. J. Agric. Food Chem. 43, 1626-1628(1995).

20) Antunes Viegas, D.; Palmeira-de-Oliveira, A.; Salgueiro, L.; Martinez-de-Oliveira, J.; Palmeira-de-Oliveira, R. Helichrysum italicum: from traditional use to scientific data. J. Ethnopharmacol. 151, 54-65 (2014).

21) Sala, A.; Recio, M.; Giner, R. M.; Máñez, S.; Tournier, H.; Schinella, G.; Ríos, J. L. Anti-inflammatory and antioxi- dant properties of Helichrysum italicum. J. Pharm. Pharmacol. 54, 365-371 (2002).

22) Guinoiseau, E.; Lorenzi, V.; Luciani, A.; Muselli, A.; Costa, J. Casanova, J.; Berti, L. Biological properties and resistance reversal effect of Helichrysum italicum(Roth) G. Don. Microbial pathogens and strategies for combating them: science, technology and education(Méndez-Vilas A. Ed.) 2013, 1073-1080 (2013).

23) European Pharmacopeia(2002). Strasbourg Cedex, France, 4th ed. Vol. 2.8.12, pp 183-184.

24） Maggi, F.; Papa, F.; Cristalli, G.; Sagratini, G.; Vittori, S.; Giuliani, C. Histochemical localization of secretion and composition of the essential oil in Melittis melissophyllum L. subp. melissophyllum from central Italy. Flavour Frag. J. 25 63-70 (2010).

25) Bicchi, C.; Cagliero, C.; Rubiolo, P. New trends in the analysis of the volatile fraction of matrices of vegetable origin: a short overview. A review. Flavour Frag. J. 26, 321-325 (2011).

26) Adams, R. P. Identification of Essential Oil Components by Gas Chromatography/Mass Spectrometry, 4th edn., Allured: Carol Stream, IL. (2007).

27) NIST 08, 2008. Mass spectral library (NIST/EPA/NIH). National Institute of Standards and Technology, Gaithersburg, USA, 2008.

28) Quassinti, L.; Lupidi, G.; Maggi, F.; Sagratini, G.; Papa, F.; Vittori, S.; Bianco, A.; Bramucci, M. Antioxidant and antiproliferative activity of Hypericum hircinum L. subsp. majus (Aiton) N. Robson essential oil. Nat. Prod. Res. 27, 862-868(2013).

29) Srinivasan, R.; Chandrasekar, M. J. N.; Nanjan, M. J.; Suresh, B. Antioxidant activity of Caesalpinia digyna root. J. Ethnopharmacol. 113, 284-291(2007).

30) Re, R.; Pellegrini, N.; Proteggente, A.; Pannala, A.; Yang, M.; Rice-Evans, C. Antioxidant activity applying an improved ABTS radical cation decolorization assay. Free Radical Bio Med. 26, 1231-1237 (1999).

31) Esparza Rivera, J. R.; Stone, M. B.; Stushnoff, C.; Pilon-Smits, E.; Kendall, P. A. Effects of ascorbic acid applied by two hydrocooling methods on physical and chemical properties of green leaf lettuce stored at $5{ }^{\circ} \mathrm{C}$. J. Food Sci. 71, S270-276 (2006).

32) Firuzi, O.; Lacanna, A.; Petrucci, R.; Marrosu, G.; Saso, L. Evaluation of the antioxidant activity of flavonoids by "ferric reducing antioxidant power" assay and cyclic voltammetry. Biochim. Biophys. Acta 1721, 174$184(2005)$. 